\title{
Trysts Tropiques: The Torrid Jungles of Science Fiction
}

\author{
Christopher B. Menadue
}

The Cairns Institute and James Cook University, Australia

\begin{abstract}
In science fiction magazines of the first half of the twentieth century, tropical environments are chaotic domains where civilised restrictions do not apply. Visitors who cross the boundary between civilisation and jungle exhibit carnal desires and violent behaviours in response to the opportunities and threats they encounter. Mysterious cities and settlements hidden in the jungle and inhabited by supernatural beings are a common feature of science fiction of this period. The tropics are 'torrid' in both a human, emotional sense, as well as in the sense of Aristotle's definition of a geographical area that is virtually uninhabitable due to the hostility of the climate (Physics, 362a33-362b29). However, by the end of the century, the tropical jungle had been transformed in science fiction into something positive and less fearsome; a rich ecological reserve, endangered, and in need of preservation. Tropical science fiction narratives reflect a changing public understanding of the tropics, and illustrate the value of science fiction as a record of the history of changes in social and cultural values.
\end{abstract}

Keywords: fiction, gender, jungle, literature, methodology, tropical

\section{Introduction}

G rom early pulp issues of the 1920s through to the 1950s, science fiction depicts rainforest and jungle environments as a place of fascination, seduction, and danger. This is mirrored in editorial and 'factual' content of magazines of the period. The organised, controlled environment of the civilized world, with its farms, roads, cities and rule of law, is in stark contrast to adjacent lawless, chaotic tropical environments. Across a liminal boundary, we enter the domain of the monstrous and are freed from the civilized constraints that inhibit us from expressing our baser instincts. In this environment, participants freely indulge in behaviour that is as liminal to their culture as the jungle is to their civilisation. Later science fiction reveals a more moderate, or positive, view of the tropics, including discussions of environmental degradation and physical symbiosis (Cowper, 1984; Herbert, 1972). There are factual articles that are similarly sympathetic; in Omni (Bower, 1979; Montgomery, 1988) and The Magazine of Fantasy and Science Fiction (Asimov, 1995). This reflects growing environmental concerns and a more realistic public understanding of the tropics. 
The corpus of text for this study is the science fiction magazine, from the launch of Amazing Stories in 1926, to the end of the twentieth century. Titles in scope for this period are described in the Locus online science fiction magazine database (Brown \& Contento, 2010), a comprehensive database of all speculative fiction titles and issues from 1896 to 2007. Content includes fantasy, science-fantasy, speculative fiction and niche markets such as Steampunk and HFY (Humanity, Fuck Yeah!). For the purpose of this study science fiction is used as an all-inclusive term. Science fiction in magazines is used as source material for cultural comparisons for two reasons: the short delay between writing and publication, and the open content possibilities of the genre. Magazines are ephemeral, usually published from new material at each printing, and have a short lead-time for publication compared to novels. Writing, publishing and reading are closely sequenced; consequently, magazine fiction may contain material whose significance arises from writers' responses to their contemporary culture. The unbounded scope of science fiction, albeit influenced by editorial decisions, allows the author more latitude to write about a broad range of interests and concerns. It is likely that the worldview found in science fiction reveals the cultural zeitgeist more clearly than other forms of fiction. Science fiction is employed as the primary data source for this reason.

\section{Methods}

A corpus of 4,431 digitized science fiction magazine issues, reflecting over $50 \%$ of professional science fiction magazine publishing from 1926 onwards, were searched for occurrences of the stemmed words 'tropic", 'jungl', and/or 'rainforest"' and the occurrences of these terms were factored with a parallel search for the stemmed groups 'vampir"', 'zomb"' and 'ghoul*'. The aim was to uncover stories that featured supernatural monsters in a tropical setting. The word 'desert' was not included as it was not possible to separate geographic uses from other meanings. The term 'tropic*' did identify some desert settings, but the majority of works discovered featured jungle environments. The magazine issues selected by the search criteria were ranked by multiplying the total occurrences of the first terms by the total of the second terms. The contents of the fifty highest-ranking issues were all examined, focusing on the context in which the search terms were found, and including outward reading of editorials, letters and factual articles. Periodicals, as Robert Scholes and Sean Latham have said, "are by their nature collaborative objects, assembled in complex interactions between editors, authors, advertisers, sales agents, and even readers" (Scholes \& Latham, 2006, p. 529), and the inclusion of non-fiction content adds to the depth of the analysis.

\section{Findings}

\section{Tropical tropes in pulp science fiction}

A girl had stepped from the jungle wall into the clearing. She wore a brief halter of furred skin with a loincloth of the same... She was beautiful and wild, emanating the aura of a cat... he could see her finely chiseled features, her gleaming white teeth, her flower-red lips. She was ravishing. Wayne's eyes caught all this in a fraction of 
a second. He felt himself turning a brilliant scarlet as much because of her laughter as because of his nakedness. The skinny six-foot scientist knew and was keenly conscious of what a ridiculous figure he must cut in her eyes and he resented it. Covering himself as best he could with a handful of grasses, Wayne started to walk toward the girl. Her beauty he had already noted, in spite of his missing glasses (Recour, 1949, p. 90).

The Swordsman of Pira by Charles Recour, published in Amazing Stories, is typical of selections from the early decades of pulp science fiction. Next, a monstrous humanoid emerges from the jungle pursuing the girl, and is promptly killed. Wayne snatches up the loincloth from the body to cover his modesty and the girl, Kayna, reveals (by sign language) that the monstrous 'Krag' is an enemy. Later, after rapidly learning to speak English, she explains that the Krags emerge by night from the jungle to abduct the women of the Pirans:

"... They are interested in only one thing: women and girls. For some reason they are incapable of breeding females and so they must steal our people to build their race..." Kayna explained bitterly (p. 93).

Narrative themes of violence towards women, sexual or physical, are commonly found in this period and such salacious material often drives the plot. In this story, the heroic Wayne is a full professor at the age of twenty-eight, a jungle war veteran, and a former captain of varsity fencing, but has been diminished by academic life:

In spite of the baggy drape of his clothes it was apparent that he had a good frame, even if it was sparsely covered with meat. His six feet of height looked less because of the perpetual stoop and roundness of his shoulders from too much time over ponderous mathematical and physical tomes, but there was really nothing wrong with him that a few weeks of rugged living wouldn't cure. (p.84)

$\mathrm{He}$ is typical of the "more attractive, more capable versions of the average reader" (Attebery, 2002 , p. 40) that we find in stories of this period. He arrives naked and unequipped in an alternative universe, meets the ravishing Kayna, and is rapidly transformed by 'rugged living'; his muscle tone and myopia soon recover, and his skill with a sword is put to good use as he works to thwart the evil plans of the Krags.

The story is set in three locations: the fearsome, wild jungle of the Krags; the island city-state of the Pirans; and, between the two, the sea, which acts as both a physical and a metaphysical boundary. The sea has liminal characteristics as a transitional space between jungle and civilisation, and provides a restful interlude for Wayne to continue his adoration of Kayna:

[they] headed out on the awful bosom of the Sea of Korus. Only it didn't really look awful, on the contrary, Wayne thought to himself it looked magnificent. Now out of the dense jungle, he could see the beauty of the setting sun, the awesome but not fearful proportions of the sea... Nor did the presence of Kayna, her long black hair wind-blown, do anything to make it unpleasant. She stood in the stern of the boat, her hand confidently guiding the tiller and there was a smile of satisfaction on her face. Wayne went over beside her. The fragrance of her took his breath away ( $p$. 105).

Wayne's obsession with Kayna is emphasised through the course of the narrative, and the narrative is richly imbued with detailed physical and sensory descriptions of Kayna's beauty; which appears to have been contrived to appeal to the fantasies of Attebery's 'average reader'. When they reach the city of Korus-tan, it is a peaceful and welcoming place, ruled by Kayna's 
benevolent father. Wayne saves the city from the Krags and stays with the besotted Kayna. Swordsman of Pira embodies all the common thematic concepts of these stories: the wildness of the jungle compared to a more ordered external world; the irresistible 'prize' female; the transformative effect of location upon characters in the story; the presence of a transitional boundary between the civilised and the wild; the identification of the jungle as the location of fearful and dangerous beings, and that civilised (male) protagonists have the capacity to confront and change the nature of the jungle and its human and non-human denizens. Wayne stays with Kayna at the end of the story; motivated by a desire to save her from the indignities and suffering she would experience if he took her home to his world. The same assumption is found in The Leopard Girl by Doug Wilcox, published in Fantastic Adventures: "She might have the keen intelligence it took to live with the most dangerous beasts. But she couldn't survive if she were thrown into civilization" (Wilcox, 1942, pp. 53-54). Civilisation is incompatible with the primal necessities of survival in the jungle environment. To cage the wild, and irresistibly sensual, jungle women is to destroy them.

The jungle is transformative, and infectiously wild, enabling visitors to be liberated from their civilised inhibitions. A lack of moral restraint is a common theme across a broad range of pulp fiction of this era, whether science fiction, detective, western or horror titles. Graphic violence, and pornographic content of pulp comics in the post-war period, led to a movement to censor them, culminating in the adoption of a voluntary code by publishers in 1954 to avoid legislative restrictions (Nyberg, 1999, pp. 52-55). This was a response to the determination between 1947 and 1948 by officials, including the FBI Director, J. Edgar Hoover, that juvenile delinquency was increased by their corrupting influence (Lent, 1999, pp. 11-12). The reduction in lurid content has been held responsible for the decline and collapse of some titles, which no longer met the demands of their readership for transgressive material, but other contributory economic and business factors affected the market of the time (Kidman, 2015). Evidence suggests a more complex model applies to the success of magazines, combining business, public opinion and readership factors, as was evident in the failing of New Worlds by the end of the 1960s. Board members of major distribution companies, shocked by the magazine content, banned it from their outlets. Champions of the 'moral majority' promoted negative and sensational news stories, and readers were alienated by a lack of consistent editorial practice. All of these were influences on the withdrawal of UK Arts Council funding, and the collapse that followed (Greenland, 1983, pp. 19-20). It seems that changes in content reflect a range of social and cultural factors indicating that magazine science fiction is representative of broader interests rather than dependent on a simple censorship model, and provides a mirror to reflect historical changes that is more nuanced than is suggested by Nyberg and Lent.

A feature of science fiction narratives that evades censorship is the transference of responsibility for transgressive behaviour to non-human or post-human characters. This transference of agency from human to supernatural protagonists provides authors and publishers with a justification for more lurid and salacious prose than would be acceptable in magazines and comic pulps featuring human adversaries, and perhaps makes it less open to public criticism as a model for human behaviours. An example of this can be found in Prometheus // by Stuart James Byrne, published in Amazing Stories (Byrne, 1948, pp. 8-87). 
The hero, Germain, has a spectacular vision in his sleep of ghouls boiling their naked human victims alive in a subterranean volcanic lake in "a scene of living Hell such as had not been imagined by Man since the days of Dante." Not satisfied with this torment alone, the "fiendish" ghouls used machines that "controlled their victims' minds and made them do anything they wanted them to do. And they filled the lake with energizing, stimulative life rays, which would not allow the men and women to die, in order that their agonies might be prolonged" (p. 54). Physical brutality is supplemented by sexual violence, orchestrated by the inhuman ghouls, and described in typically florid prose:

Here a great Bacchanalian orgy was being carried on. Hundreds of men, mingling with the ghouls ... reveled in unspeakable horror. A very beautiful dancing girl ...was made to dance suggestively on the long banquet table, naked. The men around her poked at her and tripped her. Some broke glasses in her path, and others made her dance on the broken fragments... One great brute of a man then climbed on the table and, encouraged by the satanic crowd, cruelly embraced her before them all. Then, to Germain's uncontainable horror, he took a sword from one of his companions and proceeded to chase the poor girl along the table. When he caught her, he hacked her to pieces, furiously, passionately, while the onlookers rolled off their seats with laughter or fainted from the excitement of their own perverted passion (pp. 54-55).

The ghoul leader justifies their behaviour as a necessity of moral relativism. "So it is with the nature of the Cosmos. There must always be construction and destruction. For every force exerted there must be an equal and opposite reacting force. The one phase must complement the other. Since existence is balanced between these two extremes it follows that the one extreme is no worse or no better than the other." (p. 55). A simple, often Manichean, representation of physical, spiritual or cultural values is very commonly found in all the science fiction stories studied. This is typical of pulp fiction of the first half of the twentieth century, as Jess Nevins explains:

Pulp fiction, regardless of genre, has some easily identifiable characteristics: an emphasis on adventure and drama and an avoidance of the mimetic mundane; a privileging of plot over characterization; use of dialogue and narration as means for delivering information rather than displaying authorial style; regular use and exploitation of the exotic, whether racial, sexual, socioeconomic, or geographic; simple emotions strongly expressed; repeated use of common tropes, motifs, and plot devices, to the point of rendering them clichés; adherence to the real or perceived limits of specific genres, with concurrent lack of literary experimentation; and a clear-cut moral stance, with good usually triumphing over evil (Nevins, 2014, p. 93).

Pulp fiction writers often demonstrated remarkable inventiveness and hyperbole in jungle stories to emphasise distinctions between the wild and the civilised: "The fighting man of Callisto is also a farmer - and he must be a fighter because of the swarms of vampire monkeys which infest its jungles and raid its farms" (Steele, 1943, p. 208). Editorials routinely support unsubstantiated assumptions, such as the possibility of were-animals among 'savage tribes of Africa' (Wilcox, 194, editorial note, p. 63), and historical contact between lost civilisations of Earth and Venus (Stoneham, 1948, editorial note, p. 232). The mise en scène of the tropical environment is used to justify transgressive actions, and pseudo-scientific evidence is commonly used to bolster the realism of the setting and the plausibility of the story content. 
Brian Stableford in an analysis of the allure of Edgar Rice Burroughs's 1912 pulp-serialisation Tarzan of the Apes in Interzone (1991) identifies the jungle as a means to escape civilised constraints and as a form of wish-fulfilment fantasy which is accepting of our uncivilized urges: "Tarzan of the Apes is a curious celebration of Rousseauesque ideas about the nobility of savagery and the idea that a fundamentally virtuous human nature is routinely spoiled and perverted by cultural artifice..." (p.50). Stableford describes the wild, unconstrained mythology of the jungle in Tarzan as answering universal, primitive, urges and suggests that the allure of jungle symbolism and the freedom it represents is based on fundamental human drivers, that it embodies utopian, adventurous ideals and provides a need for fantasy wish-fulfillment:

... if we were honest, there would probably be few among us who could claim to be entirely unafflicted by fantasies of doing violence... to those who annoy and frustrate us in the thousand trivial ways which everyday life permits and necessitates... Men are the masters and agents of change: [Tarzan] is at home in the jungle not because he is bestial but because he is strong enough to subject the jungle to his ennobling influence (p.51).

Despite its savagery, the jungle can be civilised, controlled and tamed by a man.

\section{Liminal spaces}

Monsters such as the Krags and the ghouls of Byrne's story leave the jungle to find their victims. Others live in the jungle but are separated from it by a defined boundary. In The Legion of Space by Jack Williamson, published in Astounding Science Fiction (Williamson, 1934), the evil Medusae, who have captured the female (civilised) love-interest of the story, live in a city which is:

A strange, amazing place... incredibly huge. All built of black metal. Surrounded with walls a full mile high, to keep back the terrible jungle. There's a colossal fortress in the center, a gigantic tower of black metal... guarded by weapons that could annihilate all the fleets of the system in an instant (p.105).

Access to the Medusa city is extremely difficult, being eventually achieved by way of a conveniently placed aqueduct, but once in the city the protagonists are helpless as the Medusae levitate and have no need of conventional roads or pathways. A more abrupt demarcation of a physical boundary is found in M. C. Pease's The Final Answer published in Science Fiction Adventures (Pease, 1953) in which the liminal space between the city and the jungle is kept scorched clear and sterile by incendiary devices. A solitary gatekeeper-cumexecutioner controls the only exit from the city, and it is common knowledge among the citizens that certain death awaits in the chaos and disorder of the jungle outside. Sorin, the heroine of the story, is exiled for rejecting the civilised, but stagnant, culture of the city, but is rescued by a Tarzan-like savage who lives in symbiotic harmony with the forces of nature. At the end of the story, however, Sorin is decreed to be unique by the symbiotic overmind of the jungle, and allowed to retain her individual identity alongside the hive-mind of other symbiotes. She desires to return to the city and reintegrate it into the world outside, and must retain her (civilised) self-identity for this purpose. The Final Answer is one of only two stories identified in which the placement of civilisation is reversed - the city is enclosed by the jungle. But in this case, as in C.T. Stoneham's The Lion's Way, published in Famous Fantastic Mysteries 
(Stoneham, 1948), the jungle is either all that is outside, or the civilisation beyond the jungle is a barrier in itself; Japanese occupying forces in the case of Stoneham's story.

Jungles are often presented as the liminal space, or physical barrier, between external civilisation and hidden cities, caverns or similar residences of evil forces, in Gods of Venus by Richard Shaver, published in Amazing Stories:

.... a vast structure lay here under these ancient trees of the jungle. From every cranny and carving... sprang countless airplants. Mosses trailed across the timeforgotten doorways and great arched windows. Orchids flung their subtle, sensuous colors from the ledges of the rock walls....Most of these ruins lie in the wilds of Venus' jungles, far from traveled routes, and are little visited or spoken of (Shaver, 1948, p. 47).

Over time, the nature and purpose of the boundary changes to match increasingly complex narratives. Jacob's Rock by Paul McAuley, published in Amazing Stories, describes tunnels and passages that form a no-man's land between jungle sanctuary and external space-habitat, the jungle being the exotic, hollow core of an asteroid inhabited by outcasts who offer protection and assistance to the heroine (McCauley, 1989). In Stolen Faces, Stolen Names by Ray Aldridge, published in Science Fiction Age, an existential journey is made through a tropical island forest by a band of clones, all called Nomun. They have been sent there to compete to be the only survivor; who is acclaimed as the original Nomun. Their progress is enforced by a lethal robot pursuer and they must navigate among trees that are living memories of the original clone (Aldridge, 1995, p. 47). In post-millennial stories the liminal space may be the whole of the focus. The narrative of Christ Butler's The Turn, published in Asimov's Science Fiction Magazine (Butler, 2007) takes place on a raft eternally following a river that divides jungle on one side from desert on the other. The raft-dwellers have no clear purpose: "Everyone on The Raft carried out their duties without hesitation, but no one knew why" (p. 182). This appears to embody the neutral, content-free nature of the liminal boundary, as is also found in The Final Answer and Swordsman of Pia, but in the more modern context may stand as a metaphor for a more broadly cultural lack of certainty of place and purpose. In this story, we learn nothing about the land to either side and although Quill, the "Archer" of the raft displays a longing to discover what the jungle conceals, he never acts on it.

\section{Changing perception of the tropical environment}

Early representations of the tropics are of a wild, dangerous, mysterious and sensual place. It is a land of opportunity: a source of raw materials (and inhabitants) for exploitation. Editorial comments and "factual" articles that support these assumptions accompany the stories. Harley Waldeyer's "Ferocious-Fantastic-Frightening" column in Fantastic Adventures offers "Some fantastic facts about the gorilla", which, it emerges is a powerful and formidable creature, and most dangerous "...in the jungle, where the great beast is among primitive surroundings" (Waldeyer, 1942, p. 37). An editorial comment on Gods of the Jungle by Nelson $\mathrm{S}$. Bond in Amazing Stories (Bond, 1942) supports the possibility of the fantastic premises of the tale despite the author misplacing Angkor in Burma rather than Cambodia:

The mural here described is no invention of the author. It actually exists. Many and ludicrous have been the attempts of savants to give a logical explanation of its 
meaning. Readers of scientific fiction, less hindered by dogma and prejudice, may be willing to accept it as factual proof that at one time in history intercourse did exist between this earth and the planet Venus (p. 232).

Bond's story begins with a classic pulp science fiction vision of the tropics: "Burma by day was beautiful - but its beauty was that of the wakened Amazon, bronze girdled and strident riding to battle with breasts straitlaced, with soft hands gripping the sword." (p.194). By night, Burma is:

A new land: a sweet, wild land of mystery and charm... of silver and shadow... cool, chaste, serene! As untouched and untouchable as the brooding gods of its people. Burma - a land of stirring song and stranger story... his nostrils scented wisps of sandalwood and musk... the faint, exotic pleading of native pipes... (p.195)

In the issue of Amazing Stories that features Swordsman of Pira, there is a factual article giving a Herodotean description of savage peoples and horrors; a simple classification of civilized and savage, and the difficulties faced in civilizing these regions:

The horribly mutilated bodies of the white men... were found here. They were staked to crevices in the supporting stone walls of the temple by wooden rods driven through their bodies. The whole grisly scene had the air of a sacrificial event.... Later investigators discovered that actually there was an Indian society, the "Xanphene," the equivalent of the leopard societies of Africa, whose function was to guard the purity of the jungle... (Yerxa, 1949, p. 23).

Another reason given for disaster is "the sheer voracity of a fecund jungle" and the prospects for colonial exploitation are poor: "In the not distant future we may see a time when the land surrounding the Amazon will be thrown open to civilization, but it will be considerably more moderate than the high powered oil-engine civilizations that white men usually like to establish." (p. 23).

In the second half of the twentieth century the tropical environment is depicted in a more sympathetic fashion, its denizens are not so simply defined, and the relative values of the civilised external world are questioned. A steady process of rehabilitation leads to an emphasis on the value of tropical environments by the end of the century, primarily in ecological and pharmaceutical terms, reflecting changing scientific knowledge and cultural awareness. This is reflected both in fiction and in factual articles and editorials. A Message To The King of Brobdingnag by Richard Cowper, published in The Magazine of Fantasy and Science Fiction (Cowper, 1984) was dedicated to James Lovelock, whose popular work Gaia: A New Look at Life on Earth had been a recent success (Lovelock, 1979). The story concerns the implementation of a genetically engineered algae crop in tropical regions by a company thinly disguised as Monsanto. Even the scientists working for the project are divided about possible outcomes:

"But what about your contract? Doesn't Monagri stipulate-"

"I don't give a whore's fuck about my contract! If we don't blow the lid right off this one, they'll only go and try it again somewhere else." (p.85)

Ernest Jaworski, director of Monsanto's Biological Sciences Program, had publicly announced Monsanto's new capacity to genetically engineer seeds only sixteen months previously, saying: "It will now be possible to introduce virtually any gene into plant cells with the ultimate goal of improving crop productivity" (The Times (Shreveport), 1983). As a result, the company received increasing criticism leading to public actions, such as the 1990 "Millions against 
Monsanto" campaign (The Organic Consumers' Association, 2017). Interests in global ecology had grown significantly since Lovelock gave his first lecture on the subject to only two attendees at Princeton in 1969 (Lovelock, 1979, Introduction). Cowper's story is culturally significant in associating the very recent introduction of genetic crop engineering with Lovelock's Gaia hypothesis - before global activism against crop engineering became commonplace. The result of tampering with the natural order is catastrophic when an aggressively competitive algal strain, which will overwhelm and out-compete all other plant life, is seeded into the wild in Far North Queensland: "We have passed a sentence of death on the biosphere, and there is no court of appeal. It is only a question of time - or God" (p.92)

A science feature that provides a more balanced perspective of jungle and civilisation is Kenneth Bower's Darwin's Archipelago, published in Omni (Bower, 1979). Bower's piece is combines a mildly negative view of the tropics with criticism of the human culture around it. A later feature article in Omni, Amazon Apothecary, recognises the value of the tropics to science (Montgomery, 1988), and the agriculturalists and farmers who were exemplars of civilization in pulp stories of the 1930s and 1940s are now the savages, who threaten the tropical ecosystem:

But if laboratory scientists are acquiring a new reverence for tropical plant life, it is not one shared by loggers, farmers, miners, and cattlemen working in tropical countries themselves. Balick points out that thanks to those people, rain forests worldwide are being destroyed at a rate of many millions of acres per year. As this land disappears, the cultures with which it is linked will vanish as well (p.42).

In 1995, Janet Asimov wrote about issues of deforestation in a similar vein:

In the past fifty years half the tropical rainforests have gone.... Entire ecosystems are being destroyed, and will never recover. Tropical rainforests play a huge role in the planet's climate, contributing oxygen and removing carbon dioxide. They also contain more species of animals and plants than anywhere else. As the forests dwindle, scientists are frantically trying to find still uncounted useful foods and possible medicines...caring for important fellow life forms like trees may insure our own survival (pp. 100-101).

Reviewers and critics have become more critical of writers who persist with outdated treatments of the tropics. When Gwyneth Jones reviewed Take Back Plenty by Colin Greenland in The New York Review of Science Fiction (Jones, 1990), she focused on his simplistic use of violent and lascivious jungle tropes. In the same issue, Robert Killheffer reviewed Kalimantan by Lucius Shepard, and quoted Shepard from his column "Stark Raving" for Ziesing's Wired (Shepard, 1990). Shepard's personal experience is that the jungle monsters are now human: "I remember being so fucking terrified, chased by this little gray Ford full of men in white shirts along a dirt road after searching for a friend at El Playon, where the death squads dumped the bodies of their victims" (Killheffer, 1990, p. 13). Killheffer praises Shepard for his rejection of previous tropical story characteristics: "Throughout the story Shepard borrows tropes from pulp jungle adventure, but he undermines them, denying the reader traditional payoffs and resolutions" (p.14).

There is not only a changing perception of the tropical environment, but also an increasing tendency in the second half of the century to mock earlier stereotypes and see them as kitsch. Earlier stories included unsubtle attempts at humour, often based in farce and innuendo: 
...he savored the heady and delicious perfumes of flowers that streamed in fine threads of scented air through their narrow glade, and peered hopefully along the jungle aisles in search of their hula girl, and her interesting goblets (Philips, 1941, p. 37).

Gordon Eklund's 1973 story The Beasts in the Jungle, published in The Magazine of Fantasy \& Science Fiction (Eklund, 1973), is a pastiche of The Island of Doctor Moreau by H. G. Wells. The story starts with a scene in which one of the male jungle explorers resists sexual assault by an amorous human/baboon hybrid; the story continues in a comedic style which mocks the earlier portrayals of human protagonists in fantastic fiction, but combines this with a more serious ecological message; relating the attitude of the animal hybrids towards their own nature and that of their maker and the disastrous outcomes of the well-meaning interventions of the humans. The crux of the story comes when the (attractive) female character teaches the peaceful, vegetarian, hybrid animals who have set up home in the jungle about Jesus, and they immediately crucify their benign gorilla-leader. This story is transitional to later stories, which are purely derisory towards the tropes of pulp fiction; in Omni, February 1986, Terry Runte satirizes the pseudo-scientific editorials and associated stories of the previous era:

Somehow by sheer coincidence the TV producer had stumbled across Mexzcapapapetalson The Great Lost Enclosed Shopping Mall of Gold. Here we have evidence that centuries before we ever thought of such things the Mayans had built this mall, conveniently located, with plenty of free parking and the kinds of bargains you can only get with volume sales (Runte, 1986, p. 118).

Writing in an editorial piece in Interzone, David Langford mocks tropical tropes portrayed in Bmovies screened during the 1991 Mexicon: "The theme of written sf was rounded off by a selection of videos all having titles like Piranha Women in the Avocado Jungle of Death. You probably had to be there" (Langford, 1993, p. 34). By the end of the twentieth century, the misinformed and sensational treatments of the early pulp era have been overthrown and ridiculed. The modern perspective on the tropical environment is more serious; it questions human roles and responsibilities for maintaining the natural environment, which are reflected in the narratives that have evolved in science fiction.

\section{The female jungle}

In science fiction of the early twentieth century, the demarcation between the wild, dangerous jungle and the civilized world is emphasised by the use of female metaphors to describe the jungle. This practice is abundant in science fiction of this early period. In Gods of Venus, the jungle is described by an Earthly visitor as feminine and mysterious: "Beneath that shining sea of soft-breasted cloud-mass lay, I knew, vast unknown seas, and great island continents covered by primeval untouched jungles" (Shaver, 1948, p. 14), and the inhabitants are decidedly risqué, to an Earthman's eyes: "Naked, artfully tattooed, sensuous, strong, active bodies, racing on errands vital to the welfare of their world, as well as the welfare of earth. Weapon-harness, their only garments!" (p.8). The jungle warriors have been transformed by the vicissitudes of tropical life and are clearly distinguishable from their urban counterparts:

These were a different stamp than the city dwellers of his race I had seen heretofore.

They were men of the swamps and forests that the Ruler had summoned to aid me in finding my affianced. They were hunters used to combat with the wild life of the 
Venusian jungles, so much more dense and riotous than the worst jungles of Earth. (p.24)

Malevolent characters and forces are generally not natural products of the jungle, which often has positive characteristics, as in the telepathic symbiosis of the world-tree in The Final Answer (Pease, 1953). In Gods of Venus, however, a sinister goddess, Nonur, portrayed in the lasciviously baroque style of the period, inhabits the hidden city:

Her beauty was undeniable, a dark brunette, her skin was white as paper, her flesh soft and shapely, her limbs undeniably graceful and supple. But her deep emeraldlit blue eyes were pale and venomous, her lips were sated with past orgies of cruelty, her fingers twitched upon her sleek thighs like a cat contemplating an approaching, unsuspecting mouse. The glittering, transparent mesh of her revealing gown was of the finest of the Elder fabrics, and she made a picture of extreme beauty, overlaid by a revulsion that has no connection with beauty, but is another thing. The beauty was a camouflage, an affectation of a vile kind, and the truth of the thing that she was all too apparent, too fearful. The bound girl beside me shuddered, pressed closer to me as if for human contact to warm away the cold chill brought by a sight of Nonur, successor to Hecate. p.67-68

Eltona, a rival, civilized goddess, reanimates cybernetic organisms to form an army with which she intends to defeat the evil Nonur. Both female characters are depicted as exceedingly beautiful, but the jungle-dwelling Nonur combines eldritch beauty with inhuman cruelty whereas Eltona, who seeks the assistance of the earthmen to defeat Nonur, is as beautiful but entirely benevolent.

This binary opposition in the portrayal of the exotic is mirrored in more recent depictions of Asian women:

When Asian Americans do appear in movies and other pop cultural venues, stereotyped and narrowly defined roles are pervasive. For example, Asian women have been frequently portrayed as passive, exotic, and humble, or at the other extreme, as oversexualized, treacherous, and evil (Lee \& Joo, 2005, p. 655).

Examples of these polar opposites can even be found in a single paragraph in mid-century science fiction:

Hank talked for a long time before we turned in - of the immense steaming jungles of Venus, of that tropic planet's girl-warriors in their gleaming ray-proof armor, racing on the crystal spider-walks they spin like great glittering cobwebs through the tremendous tree growths. He talked of the ancient love-cults whose rites and ceremonies he described at length; their struggle with the horror cult of the cruel Hecate, the Mother of Sin - the Cult of the Limping Hag. (Shaver \& McKenna, 1946, p. 24)

Exotic women are often explicitly described as having Asian, as well as animal, characteristics: "Her skin was the soft, fine ivory of the Eurasian. Ivory, shading to tawny gold with the contours of her body, deepening with the curve of her thigh, the round of her elbow, the shadowy cup of her breasts. Pantherine, too, were her eyes. Triangular eyes, long-lashed and lazy, with pupils of dusty emerald." (Bond, 1942, p. 233).

Lee and Joo (2005) state: "Cultivation theory suggests that audience perceptions toward a group are influenced by how the group is portrayed in the media" (p.655). This may explain the consistency of the characteristics of the jungle in stories of this period, when there was 
little or no external real-world evidence to contradict pseudo-scientific articles and editorial commentary. The portrayal of the role of women in early pulp science fiction closely matches Lee and Joo's stereotypes. Women are commonly seen emerging from the natural environment (Recour, 1949), and dressed inappropriately:

....it was a girl who stood in the opening, a black-haired, browned, slim girl whose smoothly tanned body was hardly concealed by the brief skin tunic she wore. She held a short spear and looked as lithe and dangerous as a tigress, her dark eyes watchful (Hamilton, 1935, p. 410).

Women can be manufactured artefacts, as in Heart of Light (Fox, 1946), or tropical symbiotes in The Leopard Girl by Don Wilcox, (Wilcox, 1942), and Herbert's Greenslaves (Herbert, 1972). The tropical setting provides writers with the opportunity to undress the female protagonists and present them as more exciting than their civilised counterpart, but only in the absence of a civilised competitor. When the emerald-eyed Lady Rakshasi departs, it is the civilised Sheila who is the preferable, sensible, alternative:

...it was as if a disturbing fever had left the room. Ramey, feeling the gaze of Luke O'Brien curious upon him, felt a stab of warmth in his cheeks, and wondered just how much an ass he had made of himself. Apparently he had done a pretty fair job of it, for the one person whose eyes would not meet his was Sheila. And strangely, now that Rakshasi was gone, it was the clear, mist-blue sanity of Sheila's eyes that Ramey wanted most to look upon. He shook himself angrily... (Bond, 1942, p. 234)

With only one exception, all the female characters in the stories examined are portrayed as overwhelmingly beautiful. The only exception is the 'crone' in Citadel of Hate by Lee Francis (Francis, 1943), but even she was beautiful in her youth, and is motivated to help the protagonists because her immortal lover neglects her in her old age. Occasionally, the roles are reversed, with a civilized woman being overwhelmed by the charms of a savagely handsome man. These are redolent of Burrough's Tarzan, as the savage man tends to have elite or royal status (Chandler, 1951), or supra-normal qualities (Pease, 1953), which, it could be argued, reinforce male dominance and status. The representation of women in these stories could be identified as an example of a cultural distinction between the nature (literally) of women and men. Sherry Ortner suggests that women:

....are seen "merely" as being closer to nature than men. That is, culture (still equated relatively unambiguously with men) recognizes that women are active participants in its special processes, but at the same time sees them as being more rooted in, or having more direct affinity with, nature. [This explains] the pan-cultural devaluation of women, for even if women are not equated with nature, they are nonetheless seen as representing a lower order of being, as being less transcendental of nature than men are (Ortner, 1974, p. 73).

The early stories, which demarcate cleanly between the 'natural' woman and the 'cultural', and 'scientific', man are standard fare of the pulp era. In parallel with other magazine content, such as advertisements for muscle-building supplements and manuals, Brian Attebery (2002) suggests that these "actions and characters" of pulp stories "embodied a cluster of beliefs and desires regarding the natural world and men's place in it" (p. 40). These beliefs include the possibility that if the average male reader was to be transported to Pira he would discover, like Wayne, renewed vigor and enhanced capabilities. This would, naturally, have a profound 
effect on the native females. Brian Stableford says in Interzone that Tarzan of the Apes, perhaps the story that epitomizes the fantastical vision of the jungle in the early twentieth century, "[is] the purest kind of romance there is, because it is one of the few novels which does not pretend that romance must, in the end, be accommodated to social institutions" (p.52). This is true of Swordsman of Pira; the freedom of romantic adventure possible in the tropical zone, cannot be transferred to the civilised domain without risk. Tropical romance between civilised and savage is only successful in the non-normative space, and Wayne's deliberation that his romance with Kayna would not survive in his former world is a realistic one.

In magazine science fiction of the post-pulp era, the representation of women reflects changing roles and perspectives. In Jacob's Rock, the hero is female and defeats an aggressive male protagonist (McCauley, 1989). She criticizes the chauvinistic male characters, who display generic stereotypes: "Men, their cold closed faces, amusement at her presumption just beneath the skin" (p.89). In Greenslaves, the female scientist Dr Rhine Kelly is portrayed as coolly professional in the jungle, alluring in the city - an apparent reversal of earlier tropes: "When they had met in the A' Chigua nightclub in Bahia, she had seemed exotic and desirable to Joao. Now, she wore a field uniform instead of gown and jewels, and her eyes held no invitation at all" (Herbert, 1972, p. 25). This may be in spite of the change of scene, however: it transpires that she has been bodily integrated into a symbiotic relationship with the tropical insect nation. Rather than this causing or promoting unconstrained and sensual behaviours that are the by-products of the tropical environment, in this instance her seriousness is an indication of the business-like and civilised approach of the insects to clearing up the mistakes made by un-civilised humans. There is a transformation over time of the representation of women in the science fiction magazines; from attractive, and ultimately submissive, stereotypes in the earliest stories to more nuanced, heroic, roles towards the end of the century. This is analogous to the changing characteristics of the jungle: from mysterious, fecund, wild and ready to be tamed by civilisation; to valued, resourceful, and rightfully opposed to destructive, neoliberal, civilisation-by-exploitation.

\section{Conclusions}

This has, by necessity, been a wide-ranging investigation of tropical science fiction tropes and their evolution over time, and limited in terms of the depth of analysis of any single element. If we consider the meticulousness of close reading (Smith, 2016), or the broad sweep of distant reading (Khadem, 2012; Moretti, 2005), this corpus-analytical approach can probably best be described as 'proximal' by comparison. The methodology used to carry out this analysis revealed stories, editorials and factual articles that would not be easily found by hand searching alone, and the time taken to locate them from a collection of over four thousand volumes would have been prohibitive without the use of digital text-searching and data-mining techniques. The approach provided an objective method of selecting sources for analysis based on theme-specific search criteria and quantitative ranking, and demanded the examination of sources that might otherwise have either been overlooked, or disregarded. Reading around the story content gave a valuable perspective on the views of contemporary 
commentators and factual content to compare with fictional and real-world values. This 'proximal' method demonstrates that quantitative digital techniques provide an opportunity to make a bias-free selection from corpus texts, to source the content for qualitative analysis regarding the relationship between content and culture.

Pulp stories in the first half of the twentieth century are clearer and more decisive than later stories. There is no compromise in early stories; the oppositions of right and wrong, civilised and savage, good and evil are clearly stated, and always resolved in favour of good, rightful and civilised protagonists. The ambiguity of later stories both parallels the changing public perspective on the tropics, and also the increasingly existential concerns of modern society. The ending of Greenslaves sees humans being physically integrated with insects to create beings that can survive the unfolding human-created environmental catastrophe. This provokes an existential crisis on the part of the narrator that would not be expected in pulp stories of the ' 30 s and ' 40 s as he fights against the conversion of himself into a hybrid being, and confronts the brain of the insect hive that has repaired his father's failing heart: Joao fought down a shiver of revulsion, said: "I'm a slave now; I'm in bondage to you." "Not true", rumbled the voice. "A slave is one who must produce wealth for another, and there is only one true wealth in all the universe - living time. Are we slaves because we have given your father more time to live? ... let the sun work on your skin and the chlorophyll in your blood, and when you come back, tell me if the sun is your slave." (p. 31,131)

The demarcation line of the liminal spaces of the pulps has changed from being a convenient boundary between good and evil to become expanded into the setting of the story, the actors looking for their own, self-aware meaning, rather than this being prescribed by the formulaic vagaries of the plot. Editorial and factual articles also reflect this change in status: the nonhuman, natural setting is portrayed as more significant, desirable and pure than the corrupt, venal and exploitative external civilisation, and is a backdrop against which we now see human exploitation of the environment as undesirable, and even savage. It appears that twentiethcentury science fiction magazine content, both fictional and non-fictional, provides clear images of changing attitudes towards, and perceptions of, the torrid zone from blatant exploitation to concerned preservation. Changes in gender roles and characteristics also evolve through these stories, and tales such as Cowper's Message To The King of Brobdingnag indicate that science fiction writing, while not necessarily at the forefront of social movements, is strongly associated with them.

\section{References}

Aldridge, R. (1995, March). Stolen faces, stolen names. Science Fiction Age, 3, 47-62.

Asimov, J. (1995, December). Science: Crazy for trees. The Magazine of Fantasy \& Science Fiction, 89, 93-101.

Attebery, B. (2002). Decoding gender in science fiction. New York, NY: Routledge.

Bond, N. S. (1942, June). Gods of the jungle. Amazing Stories, 16, 194-244.

Bower, K. (1979, February). Earth: Darwin's archipelago. Omni, 1, 16-19.

Brown, C. N., \& Contento, W. G. (2010, 2nd January, 2010). The locus index to science fiction: 2007. Retrieved from http://www.locusmag.com/index/yr2007/0start.htm 
eTropic 16.1 (2017): ‘Tropical Liminal: Urban Vampires \& Other Bloodsucking Monstrosities' Special Issue I 139

Butler, C. (2007, October-November). The turn. Asimov's Science Fiction, 31, 176.

Byrne, S. J. (1948, February). Prometheus II. Amazing Stories, 22, 8-87.

Chandler, L. (1951, May). Planet of no return. Amazing Stories, 25, 6-51.

Cowper, R. (1984, May). A message to the king of Brobdingnag. The Magazine of Fantasy \& Science Fiction, 66, 72-92.

Eklund, G. (1973, November). The beasts of the jungle. The Magazine of Fantasy \& Science Fiction, 45, 32-65.

Fox, G. F. (1946, July). Heart of light. Amazing Stories, 20, 94-106.

Francis, L. (1943, June). Citadel of hate. Fantastic Adventures, 5, 154-183.

Greenland, C. (1983). The entropy exhibition: Michael Moorcock and the British "new wave" in science fiction. London: Routledge \& Kegan Paul.

Hamilton, E. (1935, October). The six sleepers. Weird Tales, 26, 402-421.

Herbert, F. (1972, August). Greenslaves. Thrilling Science Fiction, 4-27, 131.

Jones, G. (1990, December). Review: Take back plenty by Colin Greenland. The New York Review of Science Fiction, 28, 6.

Khadem, A. (2012). Annexing the unread: A close reading of "distant reading". Neohelicon, 39(2), 409421. doi:10.1007/s11059-012-0152-y

Kidman, S. (2015). Self-regulation through distribution: Censorship and the comic book industry in 1954. Velvet Light Trap, 75, 21-37. doi:http://dx.doi.org.elibrary.jcu.edu.au/10.7560/

Killheffer, R. (1990, December). Review: Kalimantan by Lucius Shepard. The New York Review of Science Fiction, 28, 13-14.

Langford, D. (1993, September). Editorial: The ansible link. Interzone, 75, 34.

Lee, K.-Y., \& Joo, S.-H. (2005). The portrayal of Asian Americans in mainstream magazine ads: An update. Journalism and Mass Communication Quarterly, 82(3), 654-671. doi:10.1177/107769900508200311.

Lent, J. A. (1999). The comics debates internationally: their genesis, issues, and commonalities. In J. A. Lent (Ed.), Pulp demons: International dimensions of the postwar anti-comics campaign (pp. 9-14). London: Associated University Press.

Lovelock, J. E. (1979). Gaia: A new look at life on earth. New York, NY: Oxford University Press.

McCauley, P. J. (1989, March). Jacob's rock. Amazing Stories, 63, 86-118.

Montgomery, S. (1988, October). Amazon apothecary. Omni, 11, 42.

Moretti, F. (2005). World-systems analysis, evolutionary theory, "Weltliteratur". Review (Fernand Braudel Center), 28(3), 217-228.

Nevins, J. (2014). Pulp science fiction. In R. Latham (Ed.), The Oxford handbook of science fiction (pp. 93-114). Oxford: Oxford University Press.

Nyberg, A. K. (1999). Comic book censorship in the United States. In J. A. Lent (Ed.), Pulp demons: International dimensions of the postwar anti-comics campaign (pp. 41-55). London: Associated University Press.

Ortner, S. B. (1974). Is female to male as nature is to culture? In M. Z. Rosaldo \& L. Lamphere (Eds.), Woman, culture, and society (pp. 68-87). Stanford, CA: Stanford University Press.

Pease, M. C. (1953, September). The final answer. Science Fiction Adventures, 1, 6-47.

Philips, A. M. (1941, February). The mislaid charm. Unknown, 4, 9-56.

Recour, C. (1949, March). The swordsman of Pira. Amazing Stories, 23, 90-132.

Runte, T. (1986, February). Last word. Omni, 8, 118.

Scholes, R., \& Latham, S. (2006). The changing profession: The rise of periodical studies. PMLA: Publications of the Modern Language Association of America, $121(2), 517-531$.

Shaver, R. (1948, March). Gods of Venus. Amazing Stories, 22, 8-124.

Shaver, S., \& McKenna, B. (1946, July). Cult of the witch queen. Amazing Stories, 20, 8-38, 109-145.

Shepard, L. (1990). Stark raving: Remedial reading for the generation of swine. Wired, 172-174. 
Smith, B. H. (2016). What was "close reading"? The Minnesota Review, 2016(87), 57-75. doi:10.1215/00265667-3630844

Stableford, B. (1991, September). Tarzan of the apes. Interzone, 51, 50-52.

Steele, M. J. (1943, August). Warriors of other worlds. Fantastic Adventures, 5, 208.

Stoneham, C. T. (1948, October). The lion's way. Famous Fantastic Mysteries, 10, 10-103.

The Organic Consumers' Association. (2017). Millions against Monsanto. Retrieved from https://www.organicconsumers.org/campaigns/millions-against-monsanto

The Times (Shreveport). (1983, 19th January). Scientists make gene transfer. The Times, p. 10.

Waldeyer, H. (1942, June). Ferocious-fantastic-frightening: Some fantastic facts about the gorilla. Fantastic Adventures, 4, 232.

Wilcox, D. (1942, October). The leopard girl. Fantastic Adventures, 4, 50-97.

Williamson, J. (1934). The legion of space. Astounding Science Fiction, 13, 102-122.

Yerxa, F. (1949, March). The amazing Amazon. Amazing Stories, 23, 23. 